\title{
Effect of different orchard management practices on the growth and production of rejuvenated of pomegranates (Punica granatum L.) cv. Kandhari Kabuli
}

\author{
D. P. Sharma, Julius Chakma, N. Sharma and Niranjan Singh* \\ Department of Fruit Science, College of Horticulture, Dr. YS Parmar University of Horticulture and Forestry, \\ Nauni, Solan-173230 (HP), INDIA \\ *Corresponding author. E-mail: niranjangautam@gmail.com
}

Received: January 25, 2016; Revised received: December 2, 2016; Accepted: February 23, 2017

\begin{abstract}
Orchard management practices are the most important cultural tools for successful and sustainable cultivation of any fruit crop including pomegranate. Orchard management systems have an effect on growth, yield and fruit quality through their smoothening effects on the availability of nutrients, conservation of moisture and reduction of weed competition. Orchard management practices treatments viz., five orchard floor management treatments viz., $\mathrm{T}_{1}$ : Grass mulch (10cm thick), $\mathrm{T}_{2}$ : Black polythene mulch, $\mathrm{T}_{3}$ : Clean basin + Herbicidal treatment (Glyphosate $7 \mathrm{ml} /$ litre), $\mathrm{T}_{4}$ : Ridge basin + Grass mulch and $\mathrm{T}_{5}$ : Control (No mulching). The results of the experiment, black several that polythene mulch proved to be most effective in increasing plant growth $(51.80 \mathrm{~cm})$, yield $(13.05 \mathrm{~kg} / \mathrm{plant})$ of superior fruits and also in conservation of soil moisture. Grass mulch was better when compared to other orchard floor management practices in terms of growth $(47.00 \mathrm{~cm})$ and yield $(12.35 \mathrm{~kg})$. The orders of the orchard floor management practices in moisture conservation are: black polythene mulch $13.51 \%>$ grass mulch $12.38 \%>$ ridge basin + grass mulch $9.31 \%$ > clean basin + Herbicidal treatment (Glyphosate $7 \mathrm{ml} /$ litre) $9.20 \%>$ control $7.64 \%$. Orchard floor management treatments did not exert any significant effect in controlling bacterial blight disease on leaf and fruit surface.
\end{abstract}

Keywords: Disease incidence, Fruit quality, Mulching, Orchard management, Pomegranate, Yield

\section{INTRODUCTION}

Pomegranate (Punica granatum L.) is one of the ancient and highly praised favourite fruit of Mediterranean, tropical and subtropical regions of the world. India is the world's leading producer of pomegranate with nearly $50 \%$ of world's production. The total area under this fruit at present accounted to 131 thousand hectare with an annual production of 1346 thousand metric ton and productivity of $10.30 \mathrm{MT} / \mathrm{ha}$ in India. In Himachal Pradesh, total area under this fruit accounted to 2.20 thousand hectare with an annual production of 2.54 thousand metric ton (Anonymous, 2015). The productivity of Himachal Pradesh is $0.44 \mathrm{MT} / \mathrm{ha}$, which is quite low compared to national productivity of $10.30 \mathrm{MT} / \mathrm{ha}$. It is an important commercial fruit preferred by the consumer all over the world for its sweet-acidic taste, fine dessert quality and excellent blend. The fruit is also popular due to the organoleptic characteristics of the arils (i.e. the seeds), nutritional and therapeutic values for its usefulness in cancer, indigestion and leprosy cure. Pomegranate is widely considered native in the region from Iran to Northern India (Chandra et al., 2010). The fruit is commercially cultivated in Mediterranean region and in countries like Spain, Morocco, Egypt, Pakistan (Baluchistan),
Afghanistan, Iraq, Iran, China, Japan, Russia and India. Of late, this crop is gaining popularity in arid and semiarid regions of India due to its wide adaptability, higher yield, drought hardiness and tolerance to salinity (Kaulgud, 2002). Pomegranate has a deep association with the culture of Mediterranean region and Near East where it is a savoured delicacy and is an important dietary component and greatly appreciated for its medicinal properties (Stover and Mecure, 2007). Currently there is a greater interest in pomegranate juice due to its anti-oxidant activities and potential health benefits (Hess and Kadar, 2003). The anthocyanins of pomegranate have rich anti-oxidant property. The anthocyanin responsible for pigmentation of the pomegranate were isolated and identified as 3, 5diglucoside delphindin (DP-2, 5) and 3, glucoside (DP3), cynadin 3, 5-diglucoside $(\mathrm{Cy}-3,5)$ and 3-glucoside (CY-3), peralgonidin 3, 5-diglucoside $(\mathrm{Pg}-3,5)$ and 3glucoside (Pg-3) (Abubakr et al., 2013).

Orchard management is the most important cultural practices for successful and sustainable cultivation of fruit crops including pomegranate. Orchard management systems have an effect on growth, yield and fruit quality and also in minimize the pests allele and disease spread through their smoothening effects on the availability of nutrients, conservation of moisture and 
reduction of weed competition. The studies were conducted to improve growth, fruiting, fruit quality, yield and disease incidence of bacterial blight quality in rejuvenated pomegranate plants.

\section{MATERIALS AND METHODS}

The present investigation was carried out on rejuvenated pomegranate plants in the experimental orchard of Department of Fruit Science, Dr. Yashwant Singh Parmar University of Horticulture and Forestry, Solan, Nauni, (H.P.) under rain fed mid hill conditions during the year 2012 and 2013. These trees were heavily infested with bacterial blight and was showing symptoms of decline. In order to rejuvenate these plants heavy pruning was carried out. The soil is mountainous alluvial loamy soil and having $\mathrm{pH}$ 6.62, organic carbon $1.58 \%$, available $\mathrm{N}, \mathrm{P}$ and $\mathrm{K}$ were 318.64 , 16.62 and $172 \mathrm{~kg} / \mathrm{ha}$, respectively. Five mulching treatment intensities viz., $\mathrm{T}_{1}$; Grass mulch (10 cm thick), $\mathrm{T}_{2}$ : Black polythene mulch, $\mathrm{T}_{3}$ : Clean basin + Herbicidal treatment (Glyphosate 7ml/litre), $\mathrm{T}_{4}$ : Ridge basin + Grass mulch and $\mathrm{T}_{5}$ : Control (No mulching), were exercised in Randomized Block Design with three replications on uniformly 7- years old 'Kandari Kabuli' pomegranate trees. The orchard is located on the North Eastern side of hilly tract under the sub temperate, sub-humid mid-hill agro climatic zone II of Himachal Pradesh where, situated at an elevation of $1250 \mathrm{~m}$ above mean sea level at $30{ }^{\circ} 51^{\prime} \mathrm{N}$ latitude and $76{ }^{\circ} 11$ ' $\mathrm{E}$ longitude. The annual rainfall of this area ranges between 100-125 cm and the major amount of which is received during July to September, summer is moderately hot during May-June while, winter is quite severe during December-January. Orchard management treatments were give to selected trees in dormant season during March-April, 2012 while in March-April, 2013 only the corrective mulching was being uniformly carried out in all the treated plants. Observations regard- ing growth parameters, viz. annual shoot growth, trunk girth, tree spread, tree volume, pruning weight, leaf area and chlorophyll content were recorded according to standard procedures during both the years of study with the procedure of Hiscox and Israelstam (1979). The fruits were harvested carefully at full maturity and brought to the laboratory for analysis. After harvest fruit yield, fruit size, weight, fruit volume and fruit firmness were recorded with the standard procedure (A.O.A.C., 1980) to determine physical properties of fruits. The fruits were also analyzed for chemical constituents i.e., total soluble solids (TSS), titrable acidity and sugars (total, reducing and non-reducing). TSS was determined by hand refractometer at room temperature and was expressed in terms of degree $\left({ }^{0} \mathrm{~B}\right)$. The fruits and plants were in order to record the prevalence of the diseases; the incidence and severity were recorded in the pomegranate growing areas in different localities surveyed. The data generated from these investigations were appropriately computed, tabulated and analysed in accordance with procedures outlined by (Gomez and Gomez, 1984).

\section{RESULTS AND DISCUSSION}

Plant vigour: The present investigation illustrated that different orchard floor management treatments exerted significant influence on various tree vigour characters viz shoot extension growth, plant spread, plant height and tree volume as compared to control. Among all the treatment under study, $\mathrm{T}_{2}$ recorded maximum shoot extension growth with highest $(51.80 \mathrm{~cm})$. It also gave highest tree spread $(2.60 \mathrm{~m})$, tree height $(2.66 \mathrm{~m})$ and tree volume $\left(9.41 \mathrm{~m}^{3}\right)$, whereas minimum tree vigour was observed in case of $\mathrm{T}_{5}$ in both years of study (Table 1). (Taweel and Farag, 2015) also reported that the effect of different orchard floor management treatments on tree growth characters (plant height and plant spread) was significant with black polythene mulch

Table 1. Effect of different orchard floor management practices on tree growth characters of pomegranate cv. Kandhari Kabuli. (2012 and 2013).

\begin{tabular}{|c|c|c|c|c|c|}
\hline Treatment & Shoot extension growth $(\mathrm{cm})$ & Plant Spread (m) & Plant Height (m) & Tree Volume $\left(\mathrm{m}^{3}\right)$ & Fruit Volume $\left(\mathrm{m}^{3}\right)$ \\
\hline$\overline{\mathrm{T}_{1}}$ & 47.0 & 2.50 & 2.53 & 8.33 & 257.83 \\
\hline $\mathrm{T}_{2}$ & 51.8 & 2.60 & 2.66 & 9.41 & 250.16 \\
\hline $\mathrm{T}_{3}$ & 40.4 & 2.40 & 2.26 & 6.24 & 219.33 \\
\hline $\mathrm{T}_{4}$ & 49.0 & 2.31 & 2.36 & 6.59 & 240.16 \\
\hline $\mathrm{T}_{5}$ & 38.7 & 2.24 & 2.23 & 5.82 & 216.66 \\
\hline $\mathrm{CD}_{0.05}$ & 3.71 & 0.04 & 0.05 & 0.76 & 4.44 \\
\hline
\end{tabular}

Table 2. Effect of orchard floor management treatments on fruit set, fruit drop, fruit crack, total number of fruits and yield of pomegranate cv. Kandhari Kabuli. (2012 and 2013).

\begin{tabular}{|c|c|c|c|c|c|c|c|c|}
\hline \multirow{2}{*}{ Treatment } & \multirow{2}{*}{$\begin{array}{l}\text { Fruit } \\
\text { Set }(\%)\end{array}$} & \multirow{2}{*}{$\begin{array}{l}\text { Fruit } \\
\text { Drop (\%) }\end{array}$} & \multirow{2}{*}{$\begin{array}{l}\text { Fruit } \\
\text { Crack ( \% ) }\end{array}$} & \multirow{2}{*}{$\begin{array}{l}\text { No. of Fruits/ } \\
\text { Tree }\end{array}$} & \multicolumn{2}{|c|}{ Fruit size (cm) } & \multirow{2}{*}{$\begin{array}{l}\text { Fruit } \\
\text { Weight (g) }\end{array}$} & \multirow{2}{*}{$\begin{array}{l}\text { Yield } \\
(\text { Kg)/ plant }\end{array}$} \\
\hline & & & & & Diameter & Length & & \\
\hline $\mathrm{T}_{1}$ & 51.52 & 13.45 & 1.76 & 44.33 & 9.65 & 9.66 & 264.16 & 12.35 \\
\hline $\mathrm{T}_{2}$ & 53.40 & 12.32 & 1.36 & 51.66 & 9.52 & 9.55 & 252.33 & 13.05 \\
\hline $\mathrm{T}_{3}$ & 45.28 & 24.13 & 2.60 & 35.66 & 9.26 & 9.50 & 218.00 & 7.50 \\
\hline $\mathrm{T}_{4}$ & 47.47 & 20.34 & 1.98 & 39.66 & 9.39 & 9.39 & 242.16 & 6.90 \\
\hline $\mathrm{T}_{5}$ & 42.34 & 25.66 & 2.80 & 34.00 & 9.13 & 9.29 & 212.33 & 7.35 \\
\hline $\mathrm{CD}_{0.05}$ & 1.82 & 2.11 & 0.14 & 2.23 & 0.05 & 0.03 & 10.55 & 0.73 \\
\hline
\end{tabular}


Table 3. Effect of different orchard floor management treatments on physico-chemical fruit characters of pomegranate cv. Kandhari Kabuli. (2012 and 2013).

\begin{tabular}{lccccccc}
\hline Treatment & TSS $\left({ }^{\mathbf{0}} \mathbf{B r i x}\right)$ & $\begin{array}{c}\text { Titratable } \\
\text { Acidity ( \% ) }\end{array}$ & $\begin{array}{c}\text { Total Sugars } \\
(\mathbf{\%})\end{array}$ & $\begin{array}{c}\text { Reducing Sugars } \\
\mathbf{( \% )}\end{array}$ & $\begin{array}{c}\text { Non-Reducing } \\
\text { Sugars ( \% ) }\end{array}$ & $\begin{array}{c}\text { Ascorbic } \\
\text { Acid }\end{array}$ & $\begin{array}{c}\text { TSS :Acid } \\
\text { Ratio }\end{array}$ \\
\hline $\mathrm{T}_{1}$ & 12.66 & 0.43 & 11.52 & 9.31 & 2.21 & 15.67 & 31.00 \\
$\mathrm{~T}_{2}$ & 13.33 & 0.33 & 11.86 & 9.54 & 2.32 & 15.81 & 37.56 \\
$\mathrm{~T}_{3}$ & 11.43 & 0.42 & 11.30 & 9.16 & 2.14 & 13.26 & 26.76 \\
$\mathrm{~T}_{4}$ & 11.93 & 0.49 & 10.22 & 8.52 & 1.70 & 14.01 & 24.19 \\
$\mathrm{~T}_{5}$ & 11.10 & 0.54 & 9.84 & 8.40 & 1.44 & 12.82 & 20.29 \\
$\mathrm{CD}_{0.05}$ & 0.68 & 0.05 & 0.13 & 0.08 & 0.08 & 0.36 & 1.73 \\
\hline
\end{tabular}

Table 4. Effect of different orchard floor management treatments on disease severity on fruit surface of pomegranate. cv. Kandhari Kabuli. (2012 and 2013).

\begin{tabular}{|c|c|c|c|c|c|c|c|c|}
\hline \multirow[b]{2}{*}{ Treatment } & \multicolumn{4}{|c|}{ Disease severity \% on Fruit surface } & \multicolumn{4}{|c|}{ Disease severity \% on Leaf surface } \\
\hline & $\begin{array}{c}\mathrm{B}_{1} 15 \\
\text { days }(\%)\end{array}$ & $\begin{array}{c}\mathbf{B}_{2} 30 \\
\text { days }(\%)\end{array}$ & $\begin{array}{c}\mathrm{B}_{3} 45 \\
\text { days }(\%)\end{array}$ & Mean & $\begin{array}{c}B_{1} 15 \\
\text { days }(\%)\end{array}$ & $\begin{array}{c}\mathrm{B}_{2} 30 \text { days } \\
(\%)\end{array}$ & $\begin{array}{c}B_{3} 45 \\
\text { days }(\%)\end{array}$ & Mean \\
\hline $\mathbf{T}_{1}$ & 29.00 & 35.40 & 42.00 & 35.46 & 14.80 & 20.60 & 27.40 & 20.93 \\
\hline $\mathbf{T}_{2}$ & 32.20 & 38.60 & 43.80 & 38.20 & 20.00 & 26.00 & 32.60 & 26.20 \\
\hline $\mathbf{T}_{3}$ & 28.40 & 35.00 & 39.20 & 34.20 & 23.80 & 28.80 & 36.20 & 29.60 \\
\hline $\mathbf{T}_{4}$ & 34.00 & 39.20 & 47.40 & 40.20 & 16.80 & 23.00 & 30.40 & 23.40 \\
\hline $\mathbf{T}_{5}$ & 46.60 & 55.20 & 57.00 & 52.93 & 23.20 & 29.20 & 36.60 & 29.66 \\
\hline Mean & 34.04 & 40.68 & 45.88 & & 19.72 & 25.52 & 32.64 & \\
\hline \multicolumn{9}{|l|}{$\mathrm{CD}_{0.05}$} \\
\hline Factors & & C.D. & $\mathrm{SE}(d)$ & $\operatorname{SE}(\mathbf{m})$ & & & $\operatorname{SE}(d)$ & $\mathrm{SE}(\mathrm{m})$ \\
\hline Pruning & & NS & 0.42 & 0.30 & & & 0.53 & 0.38 \\
\hline Days interval & & NS & 0.33 & 0.23 & & & 0.41 & 0.29 \\
\hline Pruning $\mathrm{x}$ days & Interval & NS & 0.74 & 0.52 & & & 0.93 & 0.66 \\
\hline
\end{tabular}

Table 5. Effect of orchard floor management treatments on soil moisture content of pomegranate cv. Kandhari Kabuli. (2012 and 2013).

\begin{tabular}{|c|c|c|c|c|c|c|c|c|c|}
\hline Treatment & B1 5/5/12 & B2 19/5/1 & & B3 2/6/12 & B4 16/6/12 & B5 30/7/12 & B6 14/7/12 & B7 28/7/12 & Mean \\
\hline$\overline{T_{1}}$ & 12.04 & 12.88 & & 11.15 & 10.40 & 13.06 & 12.18 & 12.10 & 12.38 \\
\hline $\mathbf{T}_{2}$ & 13.12 & 13.93 & & 12.15 & 13.93 & 14.24 & 12.20 & 13.37 & 13.51 \\
\hline $\mathbf{T}_{3}$ & 8.04 & 8.62 & & 7.74 & 8.20 & 10.10 & 9.06 & 8.66 & 9.20 \\
\hline $\mathbf{T}_{4}$ & 10.49 & 11.05 & & 10.02 & 10.45 & 11.00 & 10.40 & 10.64 & 9.31 \\
\hline $\mathbf{T}_{5}$ & 7.02 & 7.77 & & 6.50 & 7.26 & 8.95 & 7.92 & 7.56 & 7.64 \\
\hline Mean & 9.30 & 10.02 & & 9.62 & 9.65 & 10.53 & 10.35 & 9.86 & \\
\hline \multicolumn{10}{|l|}{$\mathrm{CD}_{0.05}$} \\
\hline \multicolumn{3}{|c|}{$\begin{array}{l}\text { Factors } \\
\text { Orchard floor management }\end{array}$} & \multicolumn{2}{|l|}{ C.D. } & \multicolumn{2}{|c|}{ SE(d) } & \multicolumn{2}{|l|}{ SE(m) } & \\
\hline \multicolumn{3}{|c|}{$\begin{array}{l}\text { Orchard floor management } \\
\text { Days Interval }\end{array}$} & 1.18 & & \multicolumn{2}{|c|}{0.222} & \multicolumn{2}{|l|}{0.157} & \\
\hline \multicolumn{3}{|c|}{ Days Interval } & 0.20 & & \multicolumn{2}{|c|}{0.263} & \multicolumn{2}{|l|}{0.186} & \\
\hline \multicolumn{3}{|c|}{ Floor management $\times$ days Interval } & NS & & \multicolumn{2}{|c|}{0.588} & \multicolumn{2}{|l|}{0.416} & \\
\hline
\end{tabular}

than other orchard floor treatments in pomegranate. Table 1; as most of the metabolites were utilized for growth and vice-versa in case of $\mathrm{T}_{2}$. Maximum plant height $(2.66 \mathrm{~m})$ and shoot extension growth $(51.80 \mathrm{~cm})$ was recorded for $\mathrm{T}_{2}$. The minimum plant height $(2.24$ $\mathrm{m})$ and extension shoot growth $(38.70 \mathrm{~cm})$ was observed in $\mathrm{T}_{5}$, respectively, which was probably due to high productivity of this trait and vice-versa in case of $\mathrm{T}_{2}$ and $\mathrm{T}_{5}$ (Table 2 ). However, variable responses have been observed in respect of different orchard floor management practices in different plants. Higher plant height was recorded in custard apple with straw mulch (Taweel and Farag, 2015).

Fruiting and yield: Results obtained in present study demonstrated that the average fruit set, fruit drop, fruit cracking, number of fruits and yield were significantly influenced by different orchard floor management treatments over control. All the orchard floor management treatments have increased per cent fruit set significantly over control (Table 2). The results are in accordance with the earlier findings that percent fruit set increased significantly with various orchard floor management practices. Highest fruit set was obtained with black polythene and control registered the lowest fruit set (Taweel and Farag, 2015).

In these treatments, highest yield per plant $(13.05 \mathrm{~kg})$ and number of fruits/tree (51.66) was recorded in $\mathrm{T}_{2}$ which was at par with $T_{1}, T_{2}, T_{3}$ and $T_{4}$ in terms of yield and number of fruits per plant (Table 2). The highest fruit setting $(53.40 \%)$ was recorded in $\mathrm{T}_{2}$, which was closely followed by $(51.52 \%)$ in $\mathrm{T}_{1}$ and $(47.47 \%)$ in $\mathrm{T}_{4}$. The highest fruit drop per cent (25.66) was recorded in $\mathrm{T}_{5}$ but at par with (24.13) in $\mathrm{T}_{3}$, (20.34) in $\mathrm{T}_{4},(13.45) \mathrm{T}_{1}$ and (12.32) in $\mathrm{T}_{2}$. The highest fruit size (Diameter and Length) $9.65 \mathrm{~cm}$ and $9.66 \mathrm{~cm}$ was recorded in $\mathrm{T}_{1}$, which was closely followed by $(9.52 \mathrm{~cm}$ and $9.55 \mathrm{~cm})$ in $\mathrm{T}_{2}$ and $(9.39 \mathrm{~cm}$ and $9.39 \mathrm{~cm})$ in $\mathrm{T}_{3}$. The highest fruit crack per cent 2.8 was recorded 
in $\mathrm{T}_{5}$, which was closely followed by $(2.60)$ in $\mathrm{T}_{3}$ and (1.98) in $\mathrm{T}_{4}$. The results are in conformity with the earlier findings that there is increased fruit size, fruit weight and total yield of fruits with orchard floor management practices (Warade et al., 2009).

Fruit quality: The maximum fruit volume $\left(257.83 \mathrm{~cm}^{3}\right)$ and ascorbic acid content (15.67 $\mathrm{mg} / 100 \mathrm{~g}$ ) was observed for the treatment of $\mathrm{T}_{1}$. The minimum fruit length $(9.29 \mathrm{~mm})$ and fruit volume $\left(216.66 \mathrm{~cm}^{3}\right)$ was found in $\mathrm{T}_{5}$. Maximum TSS (13.33 ${ }^{0}$ Brix) and total sugar $(11.86 \%)$ was observed in $\mathrm{T}_{2}$, whereas minimum TSS $\left(11.10{ }^{0}\right.$ Brix and total sugar $(9.84 \%)$ was observed in $T_{5}$ respectively (Table 3 ). Maximum reducing sugars $(9.54 \%)$ and non- reducing sugar $(2.32 \%)$ were observed in $\mathrm{T}_{2}$, whereas minimum reducing sugar $(8.40 \%)$ and non-reducing sugar $(1.44 \%)$ was observed in $\mathrm{T}_{5}$ respectively (Table 3 ). The maximum titratable acidity $(0.54 \%)$ was observed in $\mathrm{T}_{5}$, whereas minimum $(0.33 \%)$ in $\mathrm{T}_{2}$. The maximum TSS: Acid ratio (37.56 \%) was observed in $\mathrm{T}_{2}$, whereas minimum TSS: Acid ratio $(20.29 \%)$ was observed in $\mathrm{T}_{5}$ (Table 3). However, (Aly et al., 2010) reported no significant difference in fruit sugars, total soluble solids and acidity in apple with the use of mulches. Furthermore, orchard floor management practices increased better fruit quality (Liu et al., 2014).

Disease incidence on fruit and leaf surface: The present investigation revealed that the disease incidence in the fruit and leaf surface were affected significantly by all the orchard management practices over control. Least disease incidence $(34.20 \%)$ on fruit surface was recorded in treatment $\mathrm{T}_{3}$ Clean basin + Herbicidal treatment (Glyphosate $7 \mathrm{ml} /$ litre) and on leaf surface $(20.93 \%)$ in $\mathrm{T}_{1}$ [Grass mulch $(10 \mathrm{~cm}$ thick)], whereas high disease incidence both on fruit surface $(52.93 \%)$ and leaf surface $(29.66 \%)$ was recorded in treatment $\mathrm{T}_{5}$ (Table 4). However, the effect of orchard management practices on the durations were non-significant and maximum disease incidence was recorded in $\mathrm{T}_{5}$ (control).

Interestingly, different readings on disease incidence were obtained from different orchard management practices. The highest disease incidence occurred on the $45^{\text {th }}$ day; both on the leaves $(36.60 \%)$ and fruit surface $(57.00 \%)$. The disease incidence was higher in the leaves as compared to the fruits. The results relating to the decrease in disease severity by orchard management practices over control are in agreement with the findings of (Riedle, 2010) in grapes and (Lemus, 2010).

Soil moisture content: Different orchard floor management treatments significantly influenced the soil moisture content in pomegranates. In present study, the treatment with $\mathrm{T}_{2}$ : black polythene mulch gave the (13.51) highest moisture content followed by $\mathrm{T}_{1}$ : grass mulch (12.38) (Table 5) and conversely the value of this parameter was found to be significantly least in control. During the course of investigation, soil moisture content was highest in $\mathrm{T}_{2}(14.24 \%)$ on $30 / 7 / 12$, as it coincided with the onset of rainy season. The present results are in accordance with the earlier findings that in general, the black polythene there is better moisture conservation in the months of no or low rainfall area in pomegranates (Chan el al., 2010 and Taweel and Farag 2015) and almond (Khokar and Sharma, 2000).

\section{Conclusion}

The results obtained in the present investigation infer that different orchard floor management treatments influenced growth and productivity of rejuvenated pomegranate plants. However, among all the treatments $T_{2}$ recorded significantly highest tree growth $(51.80 \mathrm{~cm})$ and good quality fruits (Number of fruit set $53.40 \%$, TSS $13.33^{0}$ Brix, Total Sugars 11.30 (\%), Reducing Sugars 9.54 (\%), TSS: Acid Ratio 37:56). Black polythene mulch was also helpful in maintaining soil moisture in pomegranates. The orchard floor management treatments, however, did not show any significant effect in controlling disease on the fruit and leaf surface.

\section{ACKNOWLEDGEMENTS}

Authors are highly thankful to the facilities and funds provided by Dr. Yashwant Singh Parmar University of Horticulture and Forestry, Nauni, Solan - 173230 (H.P.), India.

\section{REFERENCES}

A.O.A.C. (1980). Official methods of analysis. Association of Official Analytical Chemists, 13th editition, W Horowitz (ed.) Benjamin Franklin Station, Washington, DC. $101 \mathrm{p}$.

Abubakr, A. R., Ashraf, N. and Ashraf, M. (2013) Influence of plant Biostimulants on physio-chemical characteristics of pomegranate cv. Kandhari Kabuli. Journal of cell and tissue research, 13 (3): 3944-3952

Aly, M.A., Nagwa, A., Abd El-Megeed and Afaf, M.A. Yousif (2010). Organic fertilization, cover crops and plastic mulching effects on soil temperature and moisture, vegetative growth, yield and fruit quality of Anna Apple trees. Alexandria Science Exchange J., 31(4): 394-403

Anonymous (2015). Indian Horticulture Database 2015, National Horticulture Board, Gurgaon.

Chan, K. Y., Fahey, D. J., Newell, M. and Barchia, I. (2010). Using composted mulch in vineyards-effects on grape yield and quality. International J. Fruit Science, 10: 441 $-453$

Chandra, R., Babu K. D., Jadhav V. T., Jaime A. and Silva T. D. (2010). Origin, history and domestication of pomegranate. Fruit, Vegetable and Cereal Science and Biotechnology, 2: 1-6

Stover and Mercure, E. W. (2007). The Pomegranate-a new look at the fruit of paradise. Hort Sci., 42(5):1088-1097

Gomez, K. A. and Gomez, A. A. (1984). In: Statistical Pro- 
cedure for Agricultural Research 2nd ed. New York: Willey Interscience. Pp. 304-309

Hess, P.B. and Kades, A.A. (2003). Response of 'Wonderful' pomegranate to controlled atmosphere. Acta Hort. Proc. of 8th International conference.

Hiscox, J.D. and Israelstam, G.F. (1979). A method for the extraction of chlorophyll from leaf tissue without maceration. Canadian Journal of Botany, 57:1332-1334

Kaulgud, S.N. (2002). Pomegranate aril blackening: fungal or physiological disorder. In: Advances in arid and semi -arid fruit crops. Centre for Advanced Studies in Hort. (fruits). MPKV Rahuri Pp. 145-147

Khokar, U. U. and Sharma, M. K. (2000). Effect of different orchard floor management practices on growth and yield of almond (Prunus amygdalus) cv. Merced. The Hort. J., 9(2): 101-106

Lemus, G. (2010). Innovative methods of walnut production in South America. Acta-Horticulture, 861:191-198
Liu,Yi, Wang, Jing, Liu, Dongbi, Li, Zhiquo, Zhang, Guoshi, Zhang, Tao, Yong, Xie, Juan, Pan, Junfeng and Chen, Fang (2014). Straw mulching reduces the harmful effects of extreme hydrological and temperature conditions in Citrus Orchards. Plos one,9(1):87094:1-9

Riedle, B.M., Hanak, K., Regner, F. and Tiefenbrunner (2010). Influence of pruning measures on recovery of Bois noir-infected grapevines. Journal of Phytopathology, 158(9):628-632

Taweel A.A. and Farag, A.A. (2015). Mulching implication on productivity and fruit quality of pomegranate grown in a sandy soil. Egypt. J. Hort., 42(1):367-391

Warade, S. D., Joshi, V. R., Masalkar, S. D. and Kulkarni, S. R. (2009). Effect of different mulches on yield and quality of pomegranate. 2nd International Symposium on "Pomegranate and minor including mediterrenean fruits", University of Agricultural Sciences, Dharwad. P 104. 